\title{
Evaluation of Overactive Bladder in Type 2 Diabetes Patients with a Questionaire-Based Study
}

\author{
Tip 2 Diyabetik Hastalarda Aşırı Aktif Mesanenin Sorgulama Formu ile \\ Değerlendirilmesi
}

\author{
Levent Verim, Kadir Kayataş, Gül Babacan Abanonu*, Zerrin Alper**, \\ Ömer Yüksel** \\ Haydarpaşa Numune Training and Research Hospital, Clinic of Urology, Istanbul, Turkey \\ *Haydarpaşa Numune Training and Research Hospital, Clinic of Internal Medicine, Istanbul, Turkey \\ **Küçükbakkalköy Family Health Center, Family Physician, Istanbul, Turkey
}

\section{Abstract}

\begin{abstract}
Aim: Overactive bladder (OAB) is a common and well-known urologic condition. OAB occurs in both women and men. Diabetes mellitus (DM) is one of the most common metabolic disorders in the world and the prevalence of DM in adults has been increasing. Diabetic neuropathy can induce functional disease of multiple organs, including diabetic bladder dysfunction (DBD). DBD occurs commonly as a late complication and $\mathrm{DBD}$ is mainly characterized by poor bladder emptying, urinary retention and overflow incontinence. However, storage symptoms, as those suggestive for OAB may also affect people with DM. The aim of this study was to evaluate the prevalence of $O A B$ in people with DM compared to healthy control subjects.
\end{abstract}

Methods: We analyzed records of 212 diabetic case and 229 control subjects using the 8-item symptom bother scale of the $O A B$ questionnaire (OAB-q) (OAB-V8).

Results: Diabetic bladder overactivity was seen in $20.3 \%$ of patients with DM $(n=43)$ and $10.5 \%$ of non-diabetic control group ( $n=24)$. The $\mathrm{OAB}$ prevalence in patients with DM was approximately two-fold higher than in control subjects. $O A B$ increased with the duration of diabetes, glycosylated hemoglobin level and age. There was no significant difference in sex distribution between the groups. There is an increase in the prevalence type 2 diabetes in Turkey. DM is a common cause of reduced bladder sensation in both men and women. In this study, OAB syndrome in diabetic patients was searched. DBD is characterized by underactive (flaccid) bladder, voiding difficulty, infrequent voiding and reduced bladder sensation during urinary storage; bladder underactivity and urinary retention during urination. $O A B$ in diabetic patients is characterized by urgency (a compelling and sudden desire to void), with or without incontinence, usually with urinary frequency and nocturia.

Conclusion: $\mathrm{OAB}$ symptoms are more prevalent in diabetic people than in healthy people. OAB symptoms in DM may be considered as a predictor of the development of diabetic neuropathy. Thus, controlling the progression of DM might reduce the incidence of diabetic neuropathy and other late diabetic complications.

Keywords: Diabetes mellitus, bladder dysfunction, overactive bladder, symptom questionnaire
Öz

Amaç: Bu çalışmanın amacı toplumumuzdaki diyabetik hastalarda aşırı aktif mesane (AAM) prevalansını sağlıklı kontrol grubuyla karşılaştırmalı olarak araştırmaktır. Diyabetik nöropati sonucu mesane işlev bozukluğu dahil çoklu organ işlevi ile ilgili rahatsızlıklar gelişir. Diyabetik mesane disfonksiyonu (DMD) zayıf akımlı idrar yapma, mesanede artık idrar kalması ve taşma şeklinde inkontinans ile karakterizedir. Bunların yanısıra, AAM'yi destekleyen depolama fonksiyon semptomlarının da diyabetikleri etkilediği düşünülmektedir.

Yöntemler: Çalışmamızda AAM-8 sorgulama formu kullanarak 212 diyabetik olgu ve 229 kontrol olgusunun bulgularını değerlendirdik.

Bulgular: Diyabetik AAM olguların \%20,3'ünde ( $n=43)$, sağlıklı kontrol grubunda ise olguların \%10,5'inde ( $n=24)$ AAM saptanmıştır. Bu bulgulara göre diyabetiklerde anlamlı derecede yüksek oranda AAM bulunmuştur. Yine bulgularımıza göre, AAM oranındaki artma diyabet hastalığının süresi, glikozile hemoglobin düzeyi ve yaş ile doğrudan ilgilidir. Çalışmada her iki grup arasında cinsiyet dağılımında önemli fark bulunmamıştır. Son yıllarda Türkiye'de diabetes mellitus prevalansı artmıştır ve diyabet hastalığı, hem kadında hem de erkekte azalmış mesane duyusunun sık görülen bir nedenidir. DMD, genellikle yetersiz detrusor aktivitesi, işeme zorluğu, sık idrara gitme, depolama ve işemede azalmış idrar duyusu ile karakterizedir. Diyabetiklerin yaklaşık \%80'inde değişen derecelerde işeme işlev bozukluğu vardır. Diyabetik AAM ise, idrar kaçırma ile birlikte veya kaçırmasız ani ve engellenemeyen işeme gereksinimi, idrara sık gitme, noktüri ile karakterizedir.

Sonuç: Çalışmamızdaki bulgular, diyabetiklerde sağlıklı kişilere oranla AAM bulguları görülme sıklığının daha baskın oranda olduğu savını desteklemektedir. Bu diyabetik AAM semptomları diyabetik nöropati gelişeceğinin ön habercisi olabilir. Bu nedenle, diyabetin ilerlemesinin bilinçli kontolü ile diyabetik nöropatinin ve diğer geç diyabetik komplikasyonların oranının azaltıması söz konusu olabilir.

Anahtar Sözcükler: Diabetes mellitus, mesane disfonksiyonu, aşırı aktif mesane, sorgulama formu
Address for Correspondence/Yazışma Adresi: Levent Verim

Haydarpaşa Numune Training and Research Hospital, Clinic of Urology, İstanbul, Turkey Phone: +90 21654232 32-1639 E-mail: leventverim@hotmail.com

Received/Geliş Tarihi: 13 October 2015 Accepted/Kabul Tarihi: 28 October 2015
The Medical Bulletin of Haseki Training and Research Hospital, published by Galenos Publishing.

Haseki Tıp Bülteni,

Galenos Yayınevi tarafından basılmıştır. 


\section{Introduction}

Diabetes mellitus (DM) is a disease of abnormal glucose metabolism caused by an absolute or relative deficiency of insulin. Chronic nature of DM causes a negative impact on the patient's quality of life (QoL). Generally, the injurious effects of hyperglycemia are accompanied by characteristic long-term microvascular complications (diabetic nephropathy, neuropathy, and retinopathy) and macrovascular complications (peripheral arterial disease, coronary artery disease, and stroke) and, subsequently, numerous urological complications $(1,2)$. The most bothersome lower urinary tract symptoms (LUTS) are polyuria and urinary frequency associated with osmotic diuresis and excess fluid intake due to hyperglycemia, and metabolic disturbance. Patients with DM of sufficient duration are vulnerable to late complications, which cause serious morbidity. The most common lower urinary tract complication due to DM is classically diabetic bladder dysfunction (DBD) described as reduced sensation, increased capacity and poor bladder emptying. DBD is established in at least 8-9 years after the diagnosis of type 2 DM. DBD is not a life-threatening disorder. However, it substantially affects QoL (3). LUTS are found in approximately $80 \%$ of people diagnosed with DM and classified into storage and voiding problems (4). Overactive bladder (OAB) syndrome is a condition that there is a frequent urge to urinate during the day and night and urinary urgency with or without incontinence. Urgency is the key symptom. Urgency incontinence is the most bothersome symptom of $O A B$ and is reported in around $40 \%$ of women and $20 \%$ of men with $O A B$ symptoms. Recent studies have shown the presence of $O A B$ syndrome in a significant number of diabetic patients. The prevalence of $O A B$ in individuals older than 18 years of age is approximately $16.5 \%(5,6)$. In the practice of modern medicine, disease-specific query forms can be used for diagnostic purposes and evaluation of therapeutic results. The validity and reliability-proven inquiry form provides the opportunity to better understand the perception and ratings. It also provides standardization in the scientific work. $O A B$ questionnaire and $O A B$ symptom scores had been validated as a reliable instrument for assessing $O A B$ all over the world. In this study, a claim-based analysis by 8-item symptom bother scale of the $O A B$ questionnaire (OAB-q) (OAB-V8) was used to evaluate comparative existence of the prevalence of $O A B$ in a population with and without diabetes $(7,8)$.

\section{Methods}

This prevalence case-control study was approved by the local ethics committee. Diagnosis of DM was considered the inclusion criteria for the first group. From January to
June 2014, 212 age- and sex-matched subjects (101 female and 111 male), who attended our outpatient clinics, were eventually diagnosed with type 2 DM according to the recommendations of the American Diabetes Association $(9,10)$. Two hundred and twenty nine age- and sexmatched participants (123 female and 106 male), who had undergone health checkup in the family medicine department, were included in the study as a control group. All the subjects were aged 40 years and older and were informed about the study protocol. Written informed consent was obtained from all participants. $O A B$ can be diagnosed on the basis of subjective symptoms instead of urodynamic testing (6). The presence of OAB was assessed using the Turkish version of the OAB-V8 consisting of eight questions each of which can be graded by the patient on a 6-point scale ranging from 0 to 5; 0 (never), 1 (few), 2 (sometimes), 3 (quite a few), 4 (usually), and 5 (always). Thus, the lowest total score is 0 and highest total score is 40 with scores of higher than 11 indicating $O A B(8)$.

The component symptoms of $O A B$, urgency and urge urinary incontinence were defined as one or more episodes per week, nocturia was defined as two or more episodes per night, and daytime frequency was defined as eight or more episodes per day. Each OAB component symptom was referred to the one-month time period before the filling date of the questionnaire. The most powerful questions were 'bothersome urgency' and 'compelling and sudden desire to void' $(11,12)$. Urinalysis, fasting glucose and glycosylated hemoglobin (HbA1c) were also assessed. The collected laboratory data were analyzed within the 4 months before the survey. Incidentally, diabetic patients with active urinary tract infection (UTI) were excluded from our study because of exacerbation of pre-existing LUTS. Furthermore, patients with spinal cord injury, acute neurogenic disorders or end-stage renal disease were also excluded from the study. The demographic and clinical data including age, sex, diabetes duration and $\mathrm{HbA} 1 \mathrm{c}$ level were assessed through the comprehensive medical data.

\section{Statistical Analysis}

For all statistical tests, NCSS (Number Cruncher Statistical System) 2007\&PASS (Power Analysis and Sample Size) 2008 Statistical Software (Utah, USA) was used. All data for categorical variables were expressed as means with standard deviation (SD) for continuous variables or percentages, frequency, ratios, minimum, maximum. In the comparisons between two groups, the mean values of the continuous variables were compared using Student's t-tests. In the case of abnormally distributed variables, the Mann-Whitney U test was used. Pearson's chi-square test and Yates' continuity correction were used for comparison of qualitative data. The relationship between the parameters was compared by Spearman's correlation 
coefficient. The results were considered statistically significant when the $p$-values were defined as $p<0.01$ and $p<0.05$, respectively.

\section{Results}

A total of 441 subjects (224 female and 217 male) participated in the studies referred from urology, endocrinology and family health clinics over the period January 2014-July 2014. The demographic and clinical data are Table 1.

A total of 212 diabetic patients (101 female and 111 male) with a mean age of $60.57( \pm 9.90)$ years and 229 control subjects ( 123 female and 106 male) with a mean age of $59.08( \pm 11.13)$ years were included the study. The mean age of the diabetic group was almost the same with that of control group $(p=0.01)$. There was no significant difference in gender distribution between the two groups ( $p>0.05)$. Based on the OAB-V8 scores, 43 (20.3\%) diabetic cases and $24(10.5 \%)$ control subjects were classified as having $O A B$ syndrome (Figure 1, 2).

DM patients had a significantly higher proportion of $O A B$ than the control group $(p=0.004 ; p<0.01)$. OAB-V8 scores in diabetics and in controls were $11.77( \pm 8.4)$ and $7.23( \pm 6.21)$, respectively. In addition, OAB-V8 scores were found to be significantly higher in diabetic patients than in control subjects $(p=0.001$ and $p<0.01$, respectively). Of the 67 diabetic OAB patients, 35 (81.4\%) had urge incontinence (wet $O A B$ ) and $8(18.6 \%)$ had dry $O A B$ (without urgency incontinence). Of the 24 control subjects with $O A B, 12(50 \%)$ had urge incontinence and $12(50 \%)$ had dry OAB. The number of patients with urge incontinence was statistically significantly higher in DM group than in control group $(p=0.016$ and $p<0.01)$.
There was no significant difference in terms of age between subjects with $O A B$ and non-OAB ( $>00.05)$. However, $O A B$ syndrome was more common in females

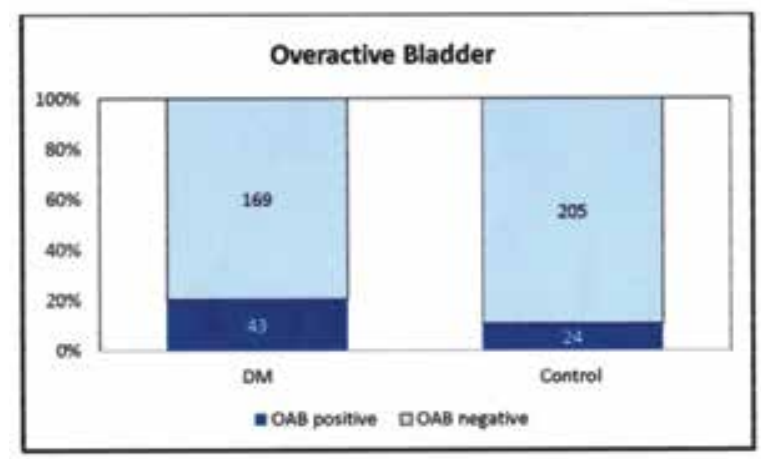

Figure 1. Distribution of overactive bladder cases DM: Diabetes mellitus, OAB: Overactive bladder

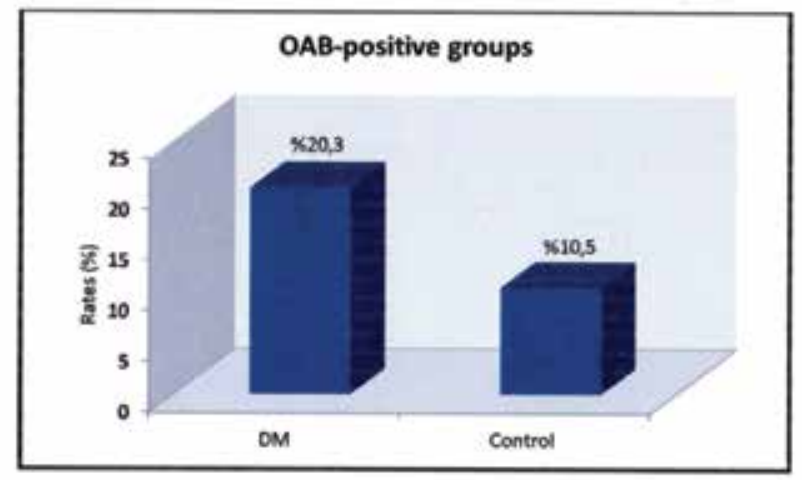

Figure 2. Rates of overactive bladder in patient and control groups DM: Diabetes mellitus

\begin{tabular}{|c|c|c|c|c|c|}
\hline & & Total $(n=441)$ & DM $(n=212)$ & Control $(n=229)$ & $\mathbf{p}$ \\
\hline \multirow[t]{2}{*}{ Age } & Min-Max & $40.00-86.00$ & $40.00-86.00$ & $40.00-86.00$ & \multirow[t]{2}{*}{$\mathrm{a} 0.01$} \\
\hline & Mean \pm SD & $59.70 \pm 11.03$ & $60.57 \pm 9.90$ & $59.08 \pm 11.13$ & \\
\hline \multirow[t]{3}{*}{ OAB-V8 score } & Min-Max & $0.00-40.00$ & $1.00-40.00$ & $0.00-37.00$ & \multirow[t]{3}{*}{$b<0.001^{* *}$} \\
\hline & Mean \pm SD & $9.41 \pm 7.68$ & $11.77 \pm 8.40$ & $7.23 \pm 6.21$ & \\
\hline & Median & 8 & 9 & 6 & \\
\hline & & n (\%) & n (\%) & n (\%) & \\
\hline \multirow[t]{2}{*}{ Gender } & Female & $224(50.8)$ & $101(47.6)$ & $123(53.7)$ & \multirow[t]{2}{*}{${ }^{c} 0.203$} \\
\hline & Male & $217(49.2)$ & $111(52.4)$ & $106(46.3)$ & \\
\hline \multicolumn{2}{|c|}{ OAB-positive rate } & $67(15.2)$ & $43(20.3)$ & $24(10.5)$ & ${ }^{c} 0.004^{* *}$ \\
\hline Urge & Wet & $47(70.1)$ & $35(81.4)$ & $12(50.0)$ & \multirow[t]{2}{*}{$d 0.016^{*}$} \\
\hline Dry & & $20(29.9)$ & $8(18.6)$ & $12(50.0)$ & \\
\hline \multicolumn{6}{|c|}{$\begin{array}{l}\text { aStudent's } t \text { test, }{ }^{b} \text { Mann Whitney } U \text { test, }{ }^{C} \text { Pearson chi square test, dYates' continuity correction test } \\
{ }^{* *} p<0.01\end{array}$} \\
\hline
\end{tabular}


than in males $(p=0.004, p<0.01)$. OAB syndrome with $D M$ was found to be statistically significantly more frequent in female diabetic patients (27 subjects, $26.7 \%$ ) than male diabetic patients (16 subjects, 14.4\%) ( $p=0.040$, $p<0.01)$. The incidence of $O A B$ in healthy females was also found to be significantly higher than in healthy males $(p=0.046, p<0.05)$. The median duration of DM in $O A B$ group and in non-OAB group was $15.70 \pm 6.70$ years and $11.00 \pm 6.31$ years, respectively. The duration of DM was significantly positively correlated with the $O A B$ syndrome in $O A B$ group compared to non-OAB group $(p=0.001$, $\mathrm{p}<0.01$ ). The mean $\mathrm{HbA} 1 \mathrm{c}$ level in diabetics with $\mathrm{OAB}$ and non-OAB was $8.60 \pm 2.05 \%$ and $7.74 \pm 149 \%$, respectively.
When compared with non-OAB group, higher $\mathrm{HbA} 1 \mathrm{c}$ level in $O A B$ group was found to be statistically significantly correlated with $O A B$ scores $(p=0.011, p<0.05)$ (Table 2).

\section{Discussion}

DM is a chronic and serious health problem worldwide. People with diabetes in high-income countries are predominantly over the age of 50 while those in low- and middle-income countries are mostly under the age of 50 . DM prevalence is rapidly increasing as a result of aging, urbanization and associated lifestyle modifications. DM and diabetic complications will continue to be a large burden especially in low- and middle-income countries

\begin{tabular}{|c|c|c|c|c|}
\hline \multicolumn{2}{|c|}{ Total subjects $(n=441)$} & \multirow{2}{*}{$\begin{array}{l}\begin{array}{l}\text { Non-OAB } \\
\text { group }(n=374)\end{array} \\
40-86\end{array}$} & \multirow{2}{*}{$\begin{array}{l}\begin{array}{l}\text { OAB group } \\
\text { (n=67) }\end{array} \\
40-84\end{array}$} & \multirow{3}{*}{$\mathrm{a} 0.289$} \\
\hline Age & Min-Max & & & \\
\hline & Mean \pm SD & $57.97 \pm 11.09$ & $59.52 \pm 10.64$ & \\
\hline \multirow[t]{2}{*}{ Gender } & Female; n (\%) & 179 (79.9) & $45(20.1)$ & \multirow[t]{2}{*}{${ }^{c} 0.004^{* *}$} \\
\hline & Male; n (\%) & 195 (89.9) & $22(10.1)$ & \\
\hline \multicolumn{2}{|c|}{ Control group ( $\mathrm{n}=\mathbf{2 2 9})$} & Non-OAB $(n=205)$ & $O A B$ group $(n=24)$ & \\
\hline \multirow[t]{2}{*}{ Age } & Min-Max & $40-86$ & $40-80$ & \multirow[t]{2}{*}{$\mathrm{a} 0.891$} \\
\hline & Mean \pm SD & $60.12 \pm 11.21$ & $59.79 \pm 10.58$ & \\
\hline \multirow[t]{2}{*}{ Gender } & Female; n (\%) & $105(85.4)$ & $18(14.6)$ & \multirow[t]{2}{*}{ d $0.046^{*}$} \\
\hline & Male; n (\%) & $100(94.3)$ & $6(5.7)$ & \\
\hline \multicolumn{2}{|c|}{ DM group $(n=212)$} & Non-OAB $(n=169)$ & OAB group $(n=43)$ & $\mathbf{p}$ \\
\hline \multirow[t]{2}{*}{ Age } & Min-Max & $40-86$ & $44-84$ & \multirow[t]{2}{*}{$\mathrm{a} 0.662$} \\
\hline & Mean \pm SD & $61.42 \pm 9.94$ & $62.16 \pm 9.84$ & \\
\hline \multirow[t]{2}{*}{ Gender } & Female; n (\%) & $74(73.3)$ & $27(26.7)$ & \multirow[t]{2}{*}{ d $0.040^{*}$} \\
\hline & Male; n (\%) & 95 (85.6) & $16(14.4)$ & \\
\hline \multirow[t]{3}{*}{ Disease duration } & Min-Max & 2 to 31 & 6 to 35 & \multirow[t]{3}{*}{$b<0.001^{*}$} \\
\hline & Mean \pm SD & $11.00 \pm 6.31$ & $15.70 \pm 6.70$ & \\
\hline & Median & 10 & 15 & \\
\hline \multirow[t]{3}{*}{$\mathrm{HbA} 1 \mathrm{c}$} & Min-Max & $5.40-14.00$ & $5.80-14.70$ & \multirow[t]{3}{*}{ b0.011* } \\
\hline & Mean \pm SD & $7.74 \pm 1.49$ & $8.60 \pm 2.05$ & \\
\hline & Median & 7.5 & 8.1 & \\
\hline aStudent's t test & $\begin{array}{l}\text { bMann Whitney U } \\
\text { test }\end{array}$ & $\begin{array}{l}\text { dYates' continuity } \\
\text { correction }\end{array}$ & test & \\
\hline${ }^{*} p<0.05$ & & ${ }^{* *} p<0.01$ & & \\
\hline
\end{tabular}


and coupled with the comparatively slow development of health systems. In 2013, 382 million people had DM in the world; this number is expected to rise to 592 million by 2035 (13).

With the worldwide rise in the prevalence of obesity and type 2 DM, it is important to understand the abnormalities in carbohydrate metabolism and insulin action. Carbohydrate metabolism in men is regulated by insulin secretion from pancreatic $\beta$-cells and glucose disposal by insulin-sensitive tissues. Insulin facilitates glucose utilization. Any defects in insulin action predispose an individual to type 2 DM (insulin resistance syndrome. Adiposity, both subcutaneous, and visceral, has been proposed to contribute to insulin resistance eventually leading to type $2 \mathrm{DM}$. Bladder dysfunction is a common complication of diabetic peripheral and autonomic neuropathy. Death rates from cardiovascular disease are about 1.7 times higher among diabetic adults than among non diabetic adults. Multiple cerebral infarction and stroke due to diabetic cerebral vasculopathy may be lateonset complications and can lead to a loss of the brain's inhibitory influence on the spino-bulbo-spinal micturition reflex. The anteromedial frontal cortex is thought to be the center for micturition, since lesions of this area lead to detrusor overactivity (DO) (14). Diabetes was the seventh leading cause of death in the United States in 2010. North America is the region with the prevalence of DM of $7.9 \%$ in the adult population (15). Chang et al. (16) have reported that the prevalence of type 2 DM among adults was $6.8 \%$ in Taiwan. A cross-sectional survey, The Turkish Epidemiology Survey of diabetes, Hypertension, Obesity and Endocrine Disease (TURDEP II) conducted in 15 January 2010-11 June 2010, comprising a nationally representative sample of 26.499 adult Turkish people (aged $\geq 20$ years) showed that the prevalence of DM was $16.5 \%$ (new $7.5 \%$ ) in Turkey. Compared to TURDEP I study performed in 1997-1998, the rate of increase for diabetes was $90 \%$, impaired glucose tolerance-106\%, and obesity was $40 \% 12$ years after the first survey and the prevalence of DM has by now reached epidemic proportions in Turkey (17). Late-onset complications of DM are also important health issues in Turkey. Lower urinary complications of DM are progressive conditions. Microvascular complications associated with DM might damage the innervations of the bladder, alter detrusor muscle function, or cause urothelial dysfunction, and may cause retinopathy and peripheral neuropathy. Diabetic patients have frequently increased bladder capacity and reduced detrusor contractility as an urodynamic finding. Furthermore, more than $25 \%$ of diabetic patients will develop debilitating and costly urological complications such as recurrent UTIs or antibiotic-resistant asymptomatic bacteriuria $(18,19)$. The aim of this study was to evaluate the prevalence of $O A B$ in the Turkish population with DM in comparison with healthy control subjects and to explore factors related with the presence of OAB. Traditionally, DBD has been described as decreased sensation, increased bladder capacity, and poor emptying. DBD might be a part of manifestation of diabetic polyneuropathy. The presentation of $O A B$ syndrome in diabetic patients remains controversial. $O A B$ syndrome is first described by Paul Abrams in 1997 and first formulated in early 2001 by the Standardization Subcommittee of the International Continence Society (6). The etiology of diabetic $O A B$ is still not well-recognized, but the genesis of $O A B$ in diabetes has been thought to develop with the central or/and peripheral nerve damage; for example, DO as a result of diabetic cerebral vasculopathy or/and increased bladder sensation because of peripheral nerve irritation $(20,21)$. On the other hand, peripheral nerve damage in diabetic cerebral vasculopathy with decreased bladder capacity and presence of mimic $O A B$ (22). Metabolic syndrome can be an etiologic pathway for the onset of $\operatorname{OAB}(23,24)$. Fayyad et al. (25) documented bothersome LUTS in 40 $\%$ of the women patients with DM. In this study, OAB syndrome associated with DM was estimated to be more frequent in women subjects than men $(26.7 \%$ and $14.4 \%$, respectively). McGrother et al. (26) have concluded that poor lifestyle factors, such as low physical activity and high energy intake causally linked to DM and obesity might contribute to the onset of OAB. Gomez et al. (27) stated that DO was the most dominant urodynamic finding in patients with DM and serious cerebral infarctions due to cerebral vasculopathy have been proposed to be the most probable cause. Liu et al. (28) have reported that HbA1c levels were similar between patients with DM with and without OAB. However, Chiu et al. (29) found that HbA1C levels increased the risk of $O A B$ in patients with type $2 \mathrm{DM}$ like in our study. The onset of geriatric $O A B$ was shown in approximately $20-40 \%$ of elderly people. The overall prevalence of $O A B$ in the United States was reported to be similar between men and women $(16.0 \%$ and $16.9 \%$, respectively) in a study published in 2003 (30). In their study including 1.359 consecutive diabetic patients, Liu et al. (28) found that the prevalence of OAB was $20.1 \%$ in women and $24.8 \%$ in men. Another survey of 3962 type 2 diabetic women carried out by Lawrence et al. (31) showed that $O A B$ affected $21.4 \%$ of diabetic patients compared to only $12.5 \%$ of non-diabetic subjects. In another research, recognition of DBD with uroflowmetry and Post Void Residual (PVR) screening has revealed 22\% type 2 diabetic women with DBD (32).

The appearance and the increased incidence of $O A B$ syndrome in DM was found to be positively correlated 
with the duration of disease. OAB was significantly more common in diabetics compared to non-diabetic controls. $O A B$ is a highly prevalent disorder with considerable impact on health-related QoL. Urinary incontinence is a serious health problem with an increasing prevalence in both genders in the elderly. $O A B$ is an important issue given its high prevalence $(33,34)$. Interestingly, the presence of wet $O A B$ increases the risk and severity of erectile dysfunction (ED) and ED also influences well-being and QoL of the men (35). $O A B$ is an important therapeutic target in patients with DM. Diabetic OAB can be managed by behavioral modification and drug therapy, both of which have been shown to be effective (36). The aim of this study was also to demonstrate the prevalence of urge incontinence in diabetic patients and to contribute to efforts aiming to improve their QoL by treating OAB.

There are some limitations in this study. First, the patients were classified only according to the data obtained using the questionnaire. $O A B$ diagnosis was estimated with only self-administered $\mathrm{OABq}-8 \mathrm{~V}$ measures without a voiding diary or urodynamic observation tests. These patients were recruited from the diabetes unit and health care control unit and were not referred to urodynamic assessment for ethical reasons. On the other hand, since $O A B$ is a symptom-based diagnosis, it would be sufficient to use validated $O A B$ questionnaires (8). Second, it was only a hospital-based cross-sectional study involving a period of short follow-up of diabetic patients. Voiding diary, flow assessment, and PVR urine test could be applied in selected patients. Third, most of the patients in this study had DM for a long period and were elderly. These two variables might have affected the results of this study. There was a lack of more detailed communitybased information about distal symmetric polyneuropathy. Further research are needed to demonstrate risk factors for and a causal link between DM and OAB.

\section{Conclusion}

We assume that, the data acquired in this study confirmed that $O A B$ symptoms are more frequent in diabetic individuals than in healthy people. DM disease duration, higher $\mathrm{HbA} 1 \mathrm{c}$ levels and age showed a statistically positive correlation with OABq-V8 scores. In conclusion, OAB symptoms in DM may be considered a predictor of development of diabetic neuropathy. Thus, controlling the progression of DM might reduce the incidence of diabetic neuropathy and other late diabetic complications.

\section{Ethics}

Ethics Committee Approval: Haydarpaşa Numune Training and Research Hospital-KAEK 2013/258 (Approval was granted on 23 Dec 2013), Informed Consent: No name questionnaire-study, Peer-review: Externally peerreviewed.

\section{Authorship Contributions}

Concept: Levent Verim. Design: Gül Babacan Abanonu Ömer Yüksel. Data Collection or Processing: Kadir Kayataş, Gül Babacan Abanonu, Zerrin Alper. Analysis or Interpretation: Levent Verim. Literature Search: Kadir Kayataş, Writing: Levent Verim.

Conflict of Interest: No conflict of interest was declared by the authors.

Financial Disclosure: The authors declared that this study received no financial support.

\section{References}

1. Keenan HA, Costacou T, Sun JK, et al. Clinical factors associated with resistance to microvascular complications in diabetic patients of extreme disease duration; the 50-year medalist study. Diabetes Care 2007;30:1995-7.

2. Adler Al, Stevens RJ, Manley SE, Bilous RW, Cull CA, Holman RR; UKPDS GROUP. Development and progression of nephropathy in type 2 diabetes; the United Kingdom Prospective Diabetes Study (UKPDS 64). Kidney Int 2003;63:225-32.

3. Basra R, Kelleher C. Disease burden of overactive bladder; quality-of-life data assessed using ICl-recommended instruments. Pharmacoeconomics 2007;25:129-42.

4. Daneshgari F, Liu G, Birder L, Hanna-Mitchell AT, Chacko S. diabetic Bladder dysfunction: current translational knowledge. J Urol 2009;182 (Suppl.):S18-S26.

5. The Overactive Bladder: From Basic Science to Clinical Management Consensus Conference. Proceedings. London, England, June 29, 1997. Urology 1997, 50(6A Suppl):1-114.

6. Abrams $P$, Andersson KE, Birder $L$, et al. Fourth International Consultation on Incontinence Recommendations of the International Scientific Committee: Evaluation and treatment of urinary incontinence, pelvic organ prolapse, and fecal incontinence. Neurourol Urodyn 2010;29:213-40.

7. Coyne K, Revicki D, Hunt T, et al. 2002. Psychometric validation of an overactive bladder symptom and health-related quality of life questionnaire: The OAB-q. Qual Life Res 2002;11:563-74.

8. Tarcan T, Mangır N, Özgür MN, Akbal C. OAB-V8 Overactive Bladder Questionnaire Validation Study. Üroloji Bülteni 2012;21:113-6.

9. Krader CG. American Diabetes Association. Diabetes clinical practice recommendations focus attention on individualization of care. Med Econ 2014;91:22.

10. Fonseca V, Blonde L, Gerstein HC. Standards of medical care in diabetes - 2007. Diabetes Care 2007;30:S4-41.

11. Coyne KS, Thompson CL, Lai JS, Sexton CC. An overactive bladder symptom and health-related quality of life short-form: Validation of the OAB-q SF. Neurourol Urodyn 2015;34:255-63.

12. Abrams P, Cardozo L, Fall M, et al; Standardisation SubCommittee of the International Continence Society. The standardization of terminology in lower urinary tract function: Report from the standardization subcommittee of the International Continence Society. Urology 2003;61:37-49.

13. Guariguata L, Whiting DR, Hambleton I, Beagley J, Linnenkamp $U$, Shaw JE. Global estimates of diabetes prevalence for 2013 and projections for 2035. Diabetes Res Clin Pract 2014;103:137-49. 
14. Kavia RBC, Dasgupta R, Fowler CJ. Functional imaging and the central control of the bladder. J Comp Neurol 2005;493:2732.

15. Allgot B, Gan D, King $H$, Lefebvre $P$, Mbanya JC, Silink $M$, et al. Diabetes Atlas. 2nd edition. Executive summary. Brussels: International Diabetes Federation; 2003:58.

16. Chang $\mathrm{CH}$, Shau WY, Jiang YD, et al. Type 2 diabetes prevalence and incidence among adults in Taiwan during 1999-2004: A national health insurance data set study. diabet Med 2010;27:636-43.

17. Satman I, Omer B, Tutuncu Y, et al. TURDEP-II Study Group; Twelve-year trends in the prevalence and risk factors of diabetes and pre diabetes in Turkish adults. Eur J Epidemiol 2013;28:169-80.

18. Liu G, Daneshgari F. diabetic Bladder Dysfunction. Chin Med J (Engl) 2014;127:1357-64.

19. Brown JS. diabetic cystopathy-what does it mean? J Urol 2009;181:13-4.

20. Yamaguchi C, Sakakibara R, Uchiyama T, et al. Bladder sensation in peripheral nerve lesions. Neurourol Urodynam 2006;25:763-9.

21. Yamaguchi $O$, Nishizawa $O$, Takeda $M$, et al. Clinical guidelines for overactive bladder. Int. J Urol 2009;16:126-42.

22. Wein AJ, Rackley RR. Overactive bladder: a better understanding of pathophysiology, diagnosis, and management. J Urol 2006;175:S5-10.

23. Chang SJ, Chiang IN, Lin CD, Hsieh CH, Yang SS. Obese children at higher risk for having overactive bladder symptoms; $A$ community-based study. Neurourol Urodyn 2015;34:123-7.

24. Uzun H, Zorba OÜ. Metabolic syndrome in female patients with overactive bladder. Urology 2012;79:72-5.

25. Fayyad AM, Hill SR, Jones G. Urine production and bladder diary measurements in women with type 2 DM and their relation to lower urinary tract symptoms and voiding dysfunction. Neurourol Urodyn 2010;29:354-8.

26. McGrother CW, Donaldson MM, Hayward T, Matthews $\mathrm{R}$, Dallosso HM, Hyde C; Leicestershire MRC Incontinence
Study Team. Urinary storage symptoms and comorbidities: a prospective population cohort study in middle-aged and older women. Age Ageing 2006;35:16-24.

27. Gomez CS, Kanagarajah P, Gousse AE. Bladder dysfunction in patients with diabetes. Curr Urol Rep 2011;12:419-26.

28. Liu RT, Chung MS, Lee WC, et al. Prevalence of overactive bladder and associated risk factors in 1359 patients with type 2 diabetes. Urology 2011;78:1040-5.

29. Chiu AF, Huang MH, Wang CC, Kuo HC. Higher glycosylated hemoglobin levels increase the risk of overactive bladder syndrome in patients with type 2 diabetes mellitus. Int J Urol 2012;19:995-1001.

30. Stewart WF, Van Rooyen JB, Cundiff GW, et al. Prevalence and burden of overactive bladder in the United States. World J Urol 2003;20:327-36.

31. Lawrence JM, Lukacz ES, Liu ILA, Nager CW, Luber KM. Pelvic floor disorders, diabetes, and obesity in women; findings from the Kaiser Permanente Continence Associated Risk Epidemiology Study. Diabetes Care 2007;30:2536-41.

32. Yu HJ, Lee WC, Liu SP, Tai TY, Wu HP, Chen J. Unrecognized voiding difficulty in female type 2 diabetic patients in the diabetes clinic; a prospective case-control study. Diabetes Care 2004;27:988-9.

33. Heldwein FL, Sanchez-Salas RE, Sanchez-Salas R, et al. Health and quality of life in urology; issues in general urology and urological oncology. Arch Esp Urol 2009;62:519-30.

34. Irwin DE, Milsom I, Hunskaar S, et al. Population-based survey of urinary incontinence, overactive bladder, and other lower urinary tract symptoms in five countries: Results of the EPIC Study. Eur Urol 2006;50:1306-14.

35. Liu RT, Chung MS, Chuang YC, et al. The presence of overactive bladder wet increased the risk and severity of erectile dysfunction in men with type 2 diabetes. J Sex Med 2012;9:1913-22.

36. Ouslander JG. Management of overactive bladder. N Engl J Med 2004;19;350:786-99. 